\title{
Intention to Halal Certification: Challenges in Increasing the Value Added of the Culinary SMEs
}

\author{
Dina Mellita *, Trisninawati, Romi Apriyadi \\ Universitas Bina Darma \\ Indonesia \\ *dinamellita@binadarma.ac.id
}

\begin{abstract}
Halal certificate is a tool for SMEs to increase the added value of products produced. By carrying out halal certificates, the product owned can be guaranteed halal status so as to provide peace for consumers, especially Muslim consumers. In addition, with halal certificates, SMEs are challenged to implement a Halal Guarantee System so that the quality of products and even the integrity of a business unit becomes better in the eyes of consumers. Halal standards and certification are mandatory in Indonesia. This is as mandated by Law No. 33 concerning Guarantee of Halal Products. In accordance with the law, there is a mandatory law for all products circulating in Indonesia to have a halal certificate. This means that SME products must also be halal-certified. The research conducted is a descriptive analysis of quantitative data to determine information on the intention and motivation of halal certificates in the eyes of SMEs. By using a questionnaire as an instrument. The sample used was 110 culinary SMEs actors with different lengths of operation and gender. By doing research in the city as known as the city of culinary, the results showed that all the SMEs have not done the halal certification yet. Nevertheless, the results of the interviews showed that all respondents were interested in conducting halal certification and understood that certification would be beneficial to the added value of their business processes.In general, this is due to business actors not yet having an understanding of the procedures for carrying out halal certification on their products. This is due to the lack of counseling and outreach about procedures for halal certification and incentives for SMEs in conducting halal certification.
\end{abstract}

\section{Keywords-Halal Certification, Culinary SMEs, Value Added}

\section{INTRODUCTION}

Small and Medium Enterprises (SMEs) have an important role in driving the economy of a nation. As a guardian of the national economic foundation, SMEs must have added value in order to develop and be highly competitive. Based on BPS data (2014), there are 56 million UKM in Indonesia and 70\% of them consist of food UKM including culinary UKM. This study aims to analyze the interests and motivations of culinary UKM in conducting halal certification. This research was conducted in one of the cities that have the most typical culinary in Indonesia, the City of Palembang. In one day, pempek maker in Palembang can produce up to 6.4 tons of traditional culinary products with various variants. And this culinary demand will increase sharply both at national and international events taking place in the city.
In order to increase the capacity and development of SMEs, the added value of SMEs themselves needs to be done. In the marketing concept, [1], perceives value as the most effective weapon in capturing target markets. In this case the value is built based on three elements, namely; Product Quality, Brand Value and Service Quality. So it is important for SMEs to identify forms of activity or innovation that meet these three elements. Thus, by conducting halal certification will meet the performance advantages of the product quality elements of the culinary UKM. Furthermore, halal certification will also increase the brand value of culinary products through increasing the prestige of UKM and the realization of emotional and spiritual dialogue, as well as the quality assurance stated by the product so that it allows SMEs to avoid the commodity trap.

As a business activity in a country that has a majority Muslim population, it is important for culinary SMEs providing food or beverage products that have halal certification. The existence of halal certification will provide a sense of security for consumers who will consume products from these SMEs. Halal standards and certification are mandatory in Indonesia. This is as mandated by Law No. 33 concerning Guarantee of Halal Products. In accordance with the law, there is a mandatory law for all products circulating in Indonesia to have a halal certificate. This means that SME products must also be halal-certified. In an effort to realize the added value of SMEs through the three elements previously described, it is necessary to first identify the interests and motivations of culinary SMEs in conducting halal certification. Furthermore, with the level of interest and motivation known, will be clearly identified as well as the factors that are obstacles for culinary SMEs in conducting halal certification.

\section{THEORETICAL REVIEW}

This study uses a theoretical basis from Theory of Planned Behavior (TPB) which was developed based on Theory of Reasoned Action (TRA) [2]. [2] Develop this theory by adding constructs that do not yet exist in TRA. This construct is called perceived behavioral control. This construct was added to the TPB to control individual behavior that is limited by its shortcomings and limitations from the lack of resources used to induce behavior [3]. Behavioral beliefs that affect 
attitudes toward behavior. Behavioral beliefs are things that encourage individuals to act. While attitudes toward behavior are individual attitudes towards behavior obtained from the beliefs generated by the behavior.

Through this theory it is known that normative beliefs affect subjective norms. Normative trust is the norm used by people who will influence in decision making. Whereas subjective norms become as individual perceptions of existing socialization to show or not behavior. These subjective norms are identical with the beliefs of someone about the actions or other people or others who need, must, or may not conduct behavior, and motivate people to know other people [4].

Then in this theory also explains the control of beliefs that influence the control of perceived behavior. Controlling beliefs is a personal experience, or people that will influence an individual's results. Perceived behavioral control is the belief that individuals have done or have never carried out certain behaviors. Clever behavior control and interpreted individual perceptions related to certain behaviors [5].

Thus in this theory, the factors that influence an individual's behavior can be identified. First, attitudes towards behavior. Attitude is not behavior, but attitude presents a preparedness for actions that lead to behavior [6]. Individuals will do things according to the attitude they have towards a behavior. The attitude towards the behavior that he considers positive will later be chosen by the individual to behave in his life. Therefore attitude is a vehicle in guiding an individual to behave.

Secondly is behavioral control perception. In this case, in behaving an individual can not fully control his behavior under the control of the individual or in a condition can be vice versa where an individual can control his behavior under the control of the individual. An individual's control of his behavior is caused by several factors, namely internal factors and also external factors. Internal factors come from within the individual such as skills, willingness, information, and others. While external factors come from the environment around the individual. Perception of behavioral control is how someone understands that the behavior exhibited is the result of control carried out by himself. The third is subjective norms, an individual will do a certain behavior if his behavior can be accepted by people who are considered important in his life can accept what he will do. Thus, normative beliefs generate awareness of pressures from the social environment or subjective norms.

Research on the intention and motivations of halal certification in SMEs has so far been very limited. The studies that have been carried out only look at halal certification from the consumer side only, as stated by [7] who argues that throughout the year, enthusiasts of halal products increased rapidly among Muslim communities even non-Muslims. The increase is due to an increase in consumer awareness to consume halal products and for Muslims this is a necessity according to religion. Quality is a guarantee of standards in food and drinks whereas for Muslim customers standards resolve their doubts in purchasing food [8]. Non-Muslim consumers around the world consume halal products because they are of high quality, safe and hygienic. Another reason for a country to provide halal food as happened in Canada, is because of the rise in Muslim immigrants [9]. [10] said that advertising, quality, norms and religion are considered as decision-making factors for halal products.

\section{METHOD}

The research design used in this study is descriptive quantitative. According to [11], descriptive research is used to gather information about a condition or situation with the ultimate goal to describe and interpret. In this study not only did the tabulation but also conducted an appropriate analysis, interpretation, comparison, identification of existing trends and relationships.

The population in this study is the typical culinary UKM of Palembang. Culinary UKM was chosen in this city because the city has succeeded in developing its food-based local economy. Based on data from the industry service, there are 165 SMEs engaged in the culinary specialties of the city of Palembang. Determination of the sample is done by determining the number of samples based on the table of determining the number of samples developed by Isaac and Michael [11]. With this table, researchers can directly determine the number of samples based on the number of populations and the desired error rate. Based on Isaac and Michael's table, and the error rate set at 5\%, the culinary UKM that will be sampled in this study is 110 UKM.

Then, in answering the research problem, primary data is collected with the help of a structured

questionnaire. The use of primary data is used for the purpose of knowing the interests and motivations of culinary UKM in conducting halal certification.

The questionnaire was constructed using a Likert scale from a scale of 1 to 5 , and consisted of 3 parts. The first part is the profile or demography of SMEs, which includes gender, age, educational background, number of employees and some questions related to the knowledge of SME owners regarding halal certification. The second part contains questions about the motivations and interests of respondents in conducting halal certification.

Furthermore, the data obtained were processed using a cross-tabulation process and analyzed using quantitative descriptive statistical methods. In this case, the questionnaire will be processed through descriptive analysis by calculating the mean value of each question.

\section{RESUlTS AND DisCUSSION}

The study was conducted on 110 culinary SME owners in the city of Palembang. Of the 110 culinary SMEs, almost $64 \%$ of these culinary SMEs are owned by women, whereas UKM owned by men is only $40 \%$. Based on these results it can be concluded that the main contributors to SMEs in the culinary or food sector in the city of Palembang have the same characteristics as SMEs in Indonesia as a whole whose main contributors are women. This phenomenon shows that SMEs contribute positively to the advancement of the quality of life 
and empowerment of women by increasing women's participation in the implementation of development.

Table 1

Demographic Profile of Respondent By Gender

\begin{tabular}{|c|c|c|}
\hline & Frequency & $\%$ \\
\hline Male & 40 & 36,4 \\
\hline Female & 70 & 63,6 \\
\hline Total & 110 & 100,0 \\
\hline
\end{tabular}

Various studies show that women in economic activities not only play a role in strengthening the economic resilience of families and communities but can also reduce the effects of economic fluctuations and contribute to efforts to reduce poverty and ensure sustainable economic growth. For this reason, Indonesia is expected to contribute to providing wider opportunities for women's entrepreneurship.

When viewed from the age group, women owners of SMEs have a high distribution, reaching $35 \%$ in the age group 45 to 54 years. In contrast, male SME owners are more dominated by the age group of 35 to 44 years, reaching $40 \%$. Observations and interviews show that women start businesses later than men, mostly because women have previously entered the labor market or worked elsewhere before doing entrepreneurship.

Table 2

Demographic Profile of Respondent By Gender and Age

\begin{tabular}{|l|l|l|l|l|l|}
\hline \multirow{2}{*}{} & \multicolumn{5}{|c|}{ AGE } \\
\cline { 2 - 6 } & $<25$ & $25-34$ & $35-44$ & $45-54$ & $>55$ \\
\hline Male & $2,5 \%$ & $12,5 \%$ & $40,0 \%$ & $35,0 \%$ & $10,0 \%$ \\
\hline Female & $0,0 \%$ & $31,4 \%$ & $28,6 \%$ & $35,7 \%$ & $4,3 \%$ \\
\hline
\end{tabular}

Based on the number of employees owned by these SMEs, almost $93 \%$ of SMEs are categorized as small businesses because they have less than 20 employees. Furthermore, it is known that the entire UKM has not yet carried out halal certification. Of the 110 SMEs, most of these SMEs, both those owned by men or women have the desire to carry out halal certification in their businesses. The obstacle they have is the lack of knowledge in the procedure to carry out the certification. When viewed from the educational background of the respondents, both male and female SME owners mostly have a high school education background so knowledge insight for certification is likely not yet understood. Furthermore, with a higher level of education, the openness of the interest of SME owners to something new in developing their business is also higher.
Table 3

Length of Distribution By Gender

\begin{tabular}{|l|c|c|}
\hline \multirow{2}{*}{ Length of Business } & \multicolumn{2}{|c|}{ Gender } \\
\cline { 2 - 3 } & Male & Female \\
\hline Less than 5 years & $42,4 \%$ & $57,6 \%$ \\
\hline 5-10 years & $30,4 \%$ & $69,6 \%$ \\
\hline More than 10 years & $38,7 \%$ & $61,3 \%$ \\
\hline
\end{tabular}

Based on the length of business, it is known that culinary SMEs are managed longer by women than men. Based on the results of data processing, in all groups of years, the dominance was more dominant. In businesses that have been established for less than five years, almost $60 \%$ are controlled by women, as well as in the old business category of 5 to 10 years and more than 10 years. Based on these results, it can be concluded that women understand better the culinary business field in this city.

Based on these results, it can be concluded that women have a high contribution and opportunity in the small and medium business sector. This is also supported by national data that shows that the employment of women in SMEs is higher than other larger business scales. Data from BPS shows that female labor force participation rates are smaller than men. In 2014, the TPAK for women was $50.22 \%$ compared to men for $83.05 \%$. Then $43 \%$ of small and medium business owners are women. However, it is more concentrated in small businesses, which contribute $56.5 \%$ of Gross Domestic Product (GDP) and this sector is also dominated by employment for the business sector by $66.7 \%$, if we explore further, $70 \%$ of the perpetrators are women (BPS, 2014).

Table 4

Intention To Halal Certification By Gender

\begin{tabular}{|l|l|l|l|}
\hline \multirow{2}{*}{ Gender } & \multicolumn{3}{|l|}{ Intention To Halal Certification } \\
\cline { 2 - 4 } & Yes & No & Uncertain \\
\hline Male & $50,0 \%$ & $37,5 \%$ & $12,5 \%$ \\
\hline Female & $54,3 \%$ & $24,3 \%$ & $21,4 \%$ \\
\hline
\end{tabular}

As a country that has a majority Muslim population, the availability of halal products is an obligation that must be fulfilled by producers. Likewise with SMEs in the food and culinary sector, providing halal products or food and beverages is an obligation. BPS data shows that overall SMEs in Indonesia, only 12 thousand of them, or $10 \%$, have halal certification. This is not comparable with several studies that show the increasing use of halal products by consumers or the public. This is also shown by the phenomenon of culinary SMEs in the city of Palembang which shows no halal certification on the products it sells.

Based on the results of interviews, it is known that SME owners are also quite aware that the existence of halal certification in their products will provide benefits and added value to their businesses. This can be seen in the average value of respondents' perceptions which reached the highest value, 
which is 4.38 . The benefits of halal certification for consumers are to provide comfort, safety and guarantee for consumers to consume existing products. In addition, with the halal certification label, it can provide the best choice for consumers in choosing a product. While the benefits obtained by producers in conducting halal certification are competitive advantage, Unique Selling Point (USP) and increasing consumer confidence.

Table 5

Educational Background by Gender

\begin{tabular}{|l|l|l|l|l|l|l|l|}
\hline \multirow{2}{*}{ Gender } & \multicolumn{7}{|c|}{ Educational Background } \\
\cline { 2 - 8 } & $\begin{array}{c}\text { Didn't Finish } \\
\text { School }\end{array}$ & $\begin{array}{c}\text { Didn't go } \\
\text { to school }\end{array}$ & Elementary & $\begin{array}{c}\text { Junior High } \\
\text { School }\end{array}$ & High School & Diploma & $\begin{array}{c}\text { Undergradua } \\
\text { te }\end{array}$ \\
\hline Male & $2,5 \%$ & $0,0 \%$ & $0,0 \%$ & $10,0 \%$ & $47,5 \%$ & $27,5 \%$ & $12,5 \%$ \\
\hline Female & $7,1 \%$ & $8,6 \%$ & $2,9 \%$ & $2,9 \%$ & $32,9 \%$ & $24,3 \%$ & $21,4 \%$ \\
\hline
\end{tabular}

The interview results also showed that the lowest average value was regarding the availability of information on halal certification for SMEs. Which has an average value of 3.79. This explains that there are still many SMEs who do not know the procedures for halal certification. The implementation of halal certification in Indonesia is held by the Halal Product Guarantee Agency (BPJPH). Based on the results of the questionnaire there are still many SMEs that do not yet know of the existence of this institution to conduct halal certification. What's more, BPJPH has very loose rules for SMEs where only 10 percent is charged. Thus the need for socialization for SMEs regarding halal certification procedures.

Besides the obstacles faced by SME owners is in obtaining an Industrial Business License (IUI). SME owners find it difficult to obtain the permit. Respondents' perceptions, in this case, have an average value of 3.87 . In organizing these permits, many documents must be attached by SMEs when managing. Whereas on the other hand, Presidential Regulation Number 98 of 2014 explains that business permits for SMEs are sufficient with a Micro Small Business License (IUMK) from the District. Besides that, another reason that is an obstacle both in applying for an IUI industrial permit or halal certification is the long and expensive processing time.

The use of halal labels needs to be shared by business actors with the public. This is based on Law No. 33 concerning the guarantee of halal products (UUJPH) [12]. Specifically Law number 33 of 2014 contains halal product guarantees (UU$\mathrm{JPH})$ to strengthen and regulate various halal regulations that have been distributed and can be referred to as paying law for regulating halal products. This halal product guarantee covers various aspects of not only medicine, food, and cosmetics but it is broader than that covering chemical, biological, genetic engineering products, as well as goods used and utilized by the public. Halal product process (PPH) as a series of activities to ensure the halal product includes the provision of materials, processing, storage, packaging, distribution, sales, and presentation of products.

The purpose of UUJPH is to ensure that every religious person worships and practices his religious teachings, provides protection and guarantees about the halal Products consumed and used by the community in accordance with the principles of protection, justice, legal certainty, accountability and transparency, effectiveness and efficiency, and professionalism. In addition, the implementation of the halal product system aims to provide comfort, safety, safety and certainty for the availability of Halal Products for the public in consuming and using Products, and to increase added value for Business Actors to produce and sell Halal Products.

Table 6

Descriptive Analysis of SMEs Perception in Intention to Halal

\begin{tabular}{|c|c|c|c|c|c|}
\hline \multicolumn{6}{|c|}{ Certification } \\
\hline & $\mathrm{N}$ & Min & Max & Mean & $\begin{array}{l}\text { Std. } \\
\text { Deviation }\end{array}$ \\
\hline M1 & 110 & 3 & 5 & 4.04 & 729 \\
\hline M2 & 110 & 3 & 5 & 3,99 & 550 \\
\hline M3 & 110 & 3 & 5 & 4,21 & 526 \\
\hline M4 & 110 & 3 & 5 & 4,04 & 649 \\
\hline M5 & 110 & 4 & 5 & 4,38 & 488 \\
\hline M6 & 110 & 3 & 5 & 4,04 & 541 \\
\hline M7 & 110 & 3 & 5 & 4,11 & 456 \\
\hline M8 & 110 & 3 & 5 & 4,12 & 483 \\
\hline M9 & 110 & 3 & 5 & 3,98 & 524 \\
\hline M10 & 110 & 3 & 5 & 3,87 & 544 \\
\hline M11 & 110 & 3 & 5 & 3,79 & 607 \\
\hline M12 & 110 & 3 & 5 & 4,04 & 574 \\
\hline M13 & 110 & 3 & 5 & 3,94 & 610 \\
\hline M14 & 110 & 3 & 5 & 3,87 & 544 \\
\hline M15 & 110 & 3 & 5 & 3,94 & 610 \\
\hline M16 & 110 & 3 & 5 & 4,14 & 550 \\
\hline
\end{tabular}

1) In this regard, to ensure the smooth process of halal production, businesses are entitled to obtain a number of things, namely information, education, and information about the JPH system; guidance in producing Halal Products; and services to get Halal Certificates quickly, efficiently, affordably, and non-discriminatory. In Article 24 of the UUJPH, business actors who submit applications for Halal Certificates must: (1) provide true, clear and honest 
that women who dominated the ownership of culinary SMEs showed that, the socialization in halal certification must be done by paying attention to the gender aspects of SME ownership and the educational background of the respondents. By paying attention to the demographic aspects of the respondents, the provision of information and outreach will be more targeted and easier to understand.

\section{REFERENCES} Certificates; (3) separating the location, location and slaughtering, processing equipment, storage, packaging, distribution, sale and presentation of Halal and non-halal products; (4) renew the Halal Certificate if the validity period of the Halal Certificate ends; and (5) reporting changes in the composition of the Material to BPJPH. For its own costs, halal certification is charged to business actors who apply for halal certificates. To expedite the implementation of JPH implementation, this law provides a role for other parties such as the government through the State Budget to facilitate the cost of halal certification for micro and small businesses. [13].

\section{CONCLUSION}

The fact that the demand for Halal foods is increasing and is now widely accepted by both Muslim and non-Muslim consumers push the business an also SMEs provides Halal foods for their consumers. It is important that potential Halal food manufacturers including SMEs understand the actual requirements for Halal certification so that they may capture their fair share of this growing market.The lack of awareness to conduct halal certification in this study occurs because the certification process is still voluntary in which the relevant parties are only waiting for the needs of business people. In addition, the absence of clear information regarding the procedures for carrying out halal certification also causes the low level of halal certification in culinary UKM. For this reason, synergy is needed from various parties, both entrepreneurs and the government and other related parties. In addition, there is a need for special socialization and incentives for SMEs to carry out halal certification. In addition, related parties must provide incentives, assistance and guidance on ways and procedures to carry out halal certification. Furthermore, the parties involved in this matter the government must provide ease and speed of bureaucratic processing of halal certification. Furthermore, the results of the study showed
[1] Ali Hasan, Marketing of Sharia Banks: The Right Way to Increase Sharia Bank Market Growth, Ghalia Indonesia, Bogor 2010

[2] Jogiyanto,2007. Behavioral Information System.Revition Edition. Yogyakarta: Andi Offset

[3] Hsu, M.H. And Chiu, C.M. (2002). Predicting Electronic Service Continuance with a Decomposed Theory of Planned Behavior". Behavior \& Information Technology.

[4] Michener, H., Delamater, Daniel J, John, Myers. 2004. Social Psychologi 5th. United Stated: Thomson Learning, Inc and Perceived Behavioral Control on the Intention of High School Business, Volume 5 No. 3, December 08.

[6] Arfan, I Lubis, 2010, 'Akuntansi Keperilakuan', Edisi dua, Salemba Empat: Jakarta

[7] Zulkarnain M. 2014.Tapping into the Lucrative Halal Market: Malaysian SMEs Perspective. International Journal of Business and Innovation. Vol. 1, Issue 6, 2014,IRC Publishers

[8] Samori, Z., \&Sabtu, N. (2014). Developing halal standard for Malaysian hotel industry: An exploratory study. Procedia-Social and Behavioral Sciences, 121, 144-157.

[9] Alhabshi, 2013. Halal Food Dilemmas: Case of Muslims in British Columbia, Canada, International Journal of Asian Social Science, vol. 3 , issue 4, 847-870

[10] Kordnaeij, A., Askaripoor, H., \&Postgraduat, A. B. 2013. Studying Affecting Factors on Customers' Attitude toward Products with Halal Brand (Case study: Kuala lumpur, Malaysia). International ResearchJournal of Applied and Basic Science, 4(10), 3138-3145.

[11] Sugiyono. 2012.Business Research Methods. Bandung :Alfabeta.

[12] Hasan, H. 2016. A Study On Awareness And Perception Towards Halal Foods Among Muslim Students In Kota Kinabalu, Sabah,Proceedings of the Australia-Middle East Conference on Business and Social Sciences 2016, Dubai (in partnership with The Journal of Developing Areas, Tennessee State University, USA) ISBN 978-0-9925622-3-6

[13] Hidayat, Asep Syarifuddin and MustolihSiradj."Halal Certification and Non-Halal Certification”.Ahkam Journal, Vol. XV No. 2, July 2015, Pp. 99-210. DOI: 10.15408/ajis.v15 i2.2864
[5] Ismail, V. Y., Zain, E. 2008.The Role of Attitudes, Subjective Norms, Students to Choose the Faculty of Economics. Journal Economics dan 